\title{
Drengestreger studier i drenge, mænd og maskulinitet
}

De stakkels drenge rejste $i$ 1980erne en baide køns- og forskningspolitisk debat og banede pejen for maskulinitetsforskningen i Danmark. Men bvor stair drengene og forskningen $i$ dag?

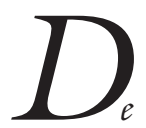

af overlæge og børnepsykiater Gideon Zlotnik var i 1984 med sit motiv og sin synsvinkel (drenges relativt større psyko-sociale problemer) en enlig svale i den kønspolitiske debat og forskning, men den skulle vise sig at have tiden for sig. Den vakte ved genudgivelsen i 1991 stor opmærksomhed og vandt et bredere publikum; ligesom den på det tidspunkt også fandt større gehør blandt kritikere og forskere (ifølge forlaget solgt i 3000 eksemplarer i 1. oplaget fra 1984 til 1991 og i 4600 eksemplarer i hele seks nye oplag fra 1991 til 1999). Den blev nu læst og forstået ind i et nyt forskningsfelt, der var ved at konsolidere sig herhjemme: forskningen i drenge og mænd ud fra en kønssynsvinkel. Samtidig angav den med sin tegning af feltet, sine 'drengestreger', den omvendte uligestilling, der har præget det helt frem til i dag.

På internationalt plan tales der i dag om "Boyhood"-studier eller om drenge-centreret forskning som et selvstændigt delfelt in- 


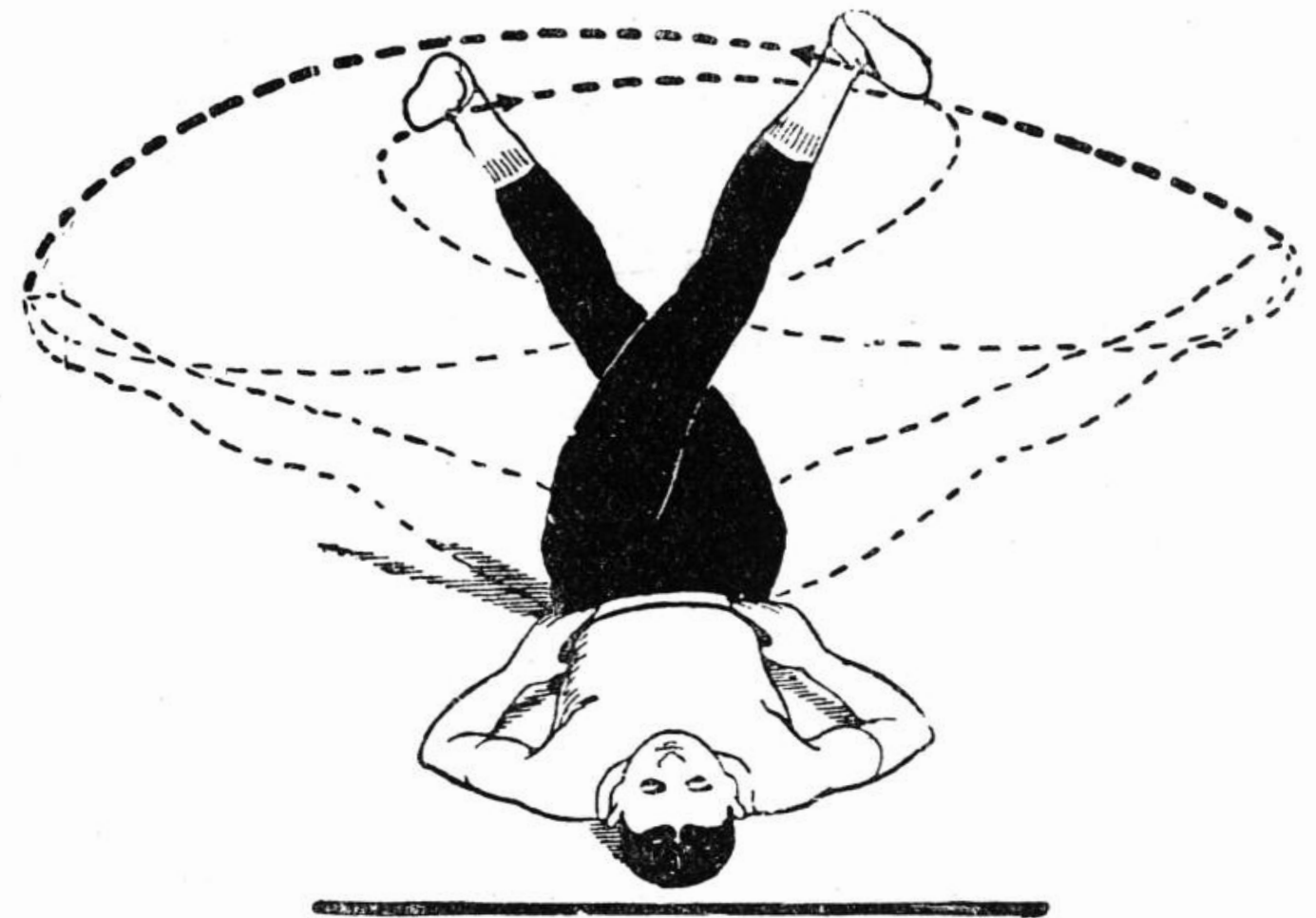

Fig. 37 . 
den for eller i dialog med det bredere felt, mande- og maskulinitetsforskningen, på den ene side og med henholdsvis de parallelle "Girlhood"-studier og kvinde- og kønsforskningen på den anden side. Der er således stor pluralitet i den aktuelle kønsforskning, og man kan spørge sig selv om det hensigtsmæssige i den stadige differentiering af feltet. Det spørgsmål vil jeg tage op til sidst, idet jeg i det følgende vil skitsere det stadigt relativt lille felt, drengestudierne, og dets samspil med i første omgang mande- og maskulinitetsforskningen.

\section{MANDE- OG MASKULINITETSSTUDIER. \\ AKTUELLE TENDENSER I DEN INTERNATIONALE FORSKNING}

Det første nummer af det nye forskningstidskrift Men and Masculinities (1998/1) bringer en åbningsartikel af den australske sociolog og uddannelsesforsker R. W. Connell [artiklen gengives her i tidsskriftet, red.]. Connell er kendt som forfatter til bl.a Gender and Power (1987) og Masculinities (1995) samt en række artikler om køn, skole og undervisning, hvor han stiller drengespørgsmålet i centrum. I "Masculinities and Globalization" foretager han en slags status over mande- og maskulinitetsforskningen internationalt set. Desuden udkaster han en slags program ved at pege på nødvendigheden af det globale perspektiv, forstået både som en internationalt orienteret nykomparatisme og især som transnationale studier i både materielle og immaterielle magtforhold. Dette program kalder Connell "the world gender order" eller på dansk “verdenskønsordenen” (Connell 1998, 7ff).

Connell starter med en kort karakteristik af det nye forskningsfelts indledende faser: fra udspringet i 1970ernes kritiske, men abstrakte kønsrolleforskning til den af feminismen inspirerede og meget overordnede kritik af patriarkatet og dets konsekvenser for mænd samt den tidlige tematiske forskning i henholdsvis homoseksualitet og psyko-seksuel maskulinitet i 1980erne til det, han kalder det etnografiske øjeblik, ved indgangen til 1990erne. Det har, ifølge Connell, været omsat i en omfattende, empirisk funderet forskning inden for en lang række fag - heriblandt nævnes sociologi, etnografi, historie og kulturstudier - i løbet af 1990erne $(1998,4)$. Vurderingen af den etnografiske drejning er, at den har bragt en tiltrængt empirisk funderet indsigt i konkrete drenges og mænds sociale livssammenhænge og en dybde-forståelse af kulturel maskulinitet, men også at dens relative nærsyn trænger til (igen) at blive kontekstualiseret af en tværgående makro-forståelse, der inddrager forhold som økonomi, produktion og politik, men også ideer og ideologier på forskellige niveauer.

Det er denne nye drejning, der gives et bud på i artiklen, idet Connell dog først præciserer, hvilke indsigter fra 1990ernes mande- og maskulinitetsstudier, den kan bygge på. Han udpeger og uddyber de for ham at se syv vitale indsigter, som han også har afprøvet på den drenge-centrerede del af forskningsfeltet og som et afsæt for egne studier i køn, skole og undervisning (Connell 1996):

1. Mangfoldighed af maskuliniteter

2. Hierarki og hegemoni

3. Kollektive maskuliniteter

4. Kroppe som arenaer

5. Aktiv konstruktion

6. Modsigelser og modsætninger

7. Dynamik

De syv indsigter kan ses som udtryk for en tilstræbt forskelstænkning, der ligger i forlængelse af den samtidige poststrukturalistiske bølge inden for human- og samfundvidenskaberne - og også i 1990ernes kvindeforskning. De tre forste indsigter repræsenterer således en tænkning i forskelle mellem drenge og mænd i tid og rum, i magtrelationer mellem mandlige individer og grupper og i hierarkier mellem forskellige former for symbolsk maskulinitet (som jægeren, soldaten etc.). Omdrejningspunk- 
tet for såvel forskelle som ligheder mellem mænd er, ifølge Connell, den maskuline krop, der bliver et brydningsfelt mellem de individuelle og de kollektive maskuliniteter.

De sidste tre indsigter repræsenterer tendentielt en mere radikal forskelstænkning, idet der her skitseres forskelsrelationer i både det enkelte subjekt, den enkelte krop og den enkelte sociale eller symbolske enhed. I umiddelbar forlængelse af disse indsigter ligger en forståelse af maskulinitet som noget, der udspilles i den sociale interaktion, dvs. som noget, der gøres, frem for noget, der er, noget processuelt og dynamisk. Til trods herfor kritiseres Connell for at fastholde et afsæt i en klassisk strukturalistisk og essentialiserende kønstænkning af de britiske sociologer Chris Haywood og Martin Mac an Ghaill (1997), der lige som Connell har den drengecentrerede skoleforskning som eget afsæt, og hvis kritik jeg skal referere til i det følgende.

\section{FRA STANDPUNKTSTEORI OG}

\section{IDENTITETSPOLITIK TIL}

\section{PERFORMANCETEORI OG DIALOGISME}

Ifølge Haywood og Ghaill (1997), så er en stor del af mande- og maskulinitetsforskningen, også Connell's, stadig præget af sit udspring $\mathrm{i}$ et materialistisk teorigrundlag $\mathrm{i}$ form af især ny-marxisme og psykoanalyse. Grundlæggende er opfattelsen her, at sociale og symbolske strukturer (re)producerer maskulinitet, modificeret af lokale forhold og variationer. Som eksempler på en sådan tilgang nævnes desuden en kanonisk forsker i feltet som Jeff Hearn (1987), der har sat fokus på socio-kulturelle magtforhold og uligheder mellem drenge og mænd og på, hvad de betyder for drenges og mænds identitet. Dog peger de også på, at Connell f.eks. i Masculinities fra 1995 har udviklet en forståelse af identitet, som adskiller sig fra både en biologisk og en social-konstruktivistisk determinisme ved at tage $\mathrm{i}$ betragtning, hvordan individuelle liv og kroppe på den ene side og kollektive sociale og kultu- relle forhold på den anden side forbindes og interagerer. Samtidig klargør han her, hvordan der etableres et komplekst hierarki af maskuliniteter med en konfliktfyldt relation mellem hegemonisk og marginaliseret maskulinitet i partikulære kønsregimer. Hermed er han, ifølge de to forfattere, også på vej over i en mere dynamisk forståelse, selvom identitet stadig forstås som et spejlingsforhold mellem struktur og individ.

Som et alternativ fremhæves netop de drenge-orienterede studier, sådan som de ifølge de to forfattere især er bedrevet inden for den omfattende (fortrinsvis angloamerikanske) forskning i relation til skole, undervisning og uddannelse eller fritidsinstitutioner. De peger her på studier af $\mathrm{M}$. Mac an Ghaill (1994) og A. Kehily og M. Nayak (1996), der har demonstreret, hvordan identitet kan opfattes som en både flydende og fragmenteret, processuel og heterogen størrelse. Ifølge de to forfattere er der her tale om en større konsekvens i brugen af poststrukturalistiske teorier (f.eks. Foucaults diskursbegreb), der bidrager til at dekonstruere de metafysiske identitets- og dermed maskulinitetsforståelser og etablere et alternativt grundlag, bl.a. ved at erstatte det psykologiske begreb identitet med et diskursivt begreb om subjektet og subjektivitet. Det diskursive subjekt forstås hos Haywood og Ghaill (1997) som sammensat af forskellige, kontekstbundne subjektpositioner og af henholdsvis en symbolsk, en social og en kropslig/materiel dimension. Det diskursive subjekt manifesteres og justeres gennem talehandlinger og sprogytringer i den sociale interaktion, og som det påpeges, så lægges der derfor også i studier som de nævnte mere vægt på det performative aspekt og på forhold som sprog, fortælling og æstetik. Som et yderligere eksempel nævnes studier af B. Davies (1995 og 1997), der arbejder med "critical literacy", dvs. en kønskritisk læse- og skrivepædagogik, hvor eleverne arbejder med og forholder sig til egne og andres tekster. Et andet studie, der repræsenterer denne nyudvik- 


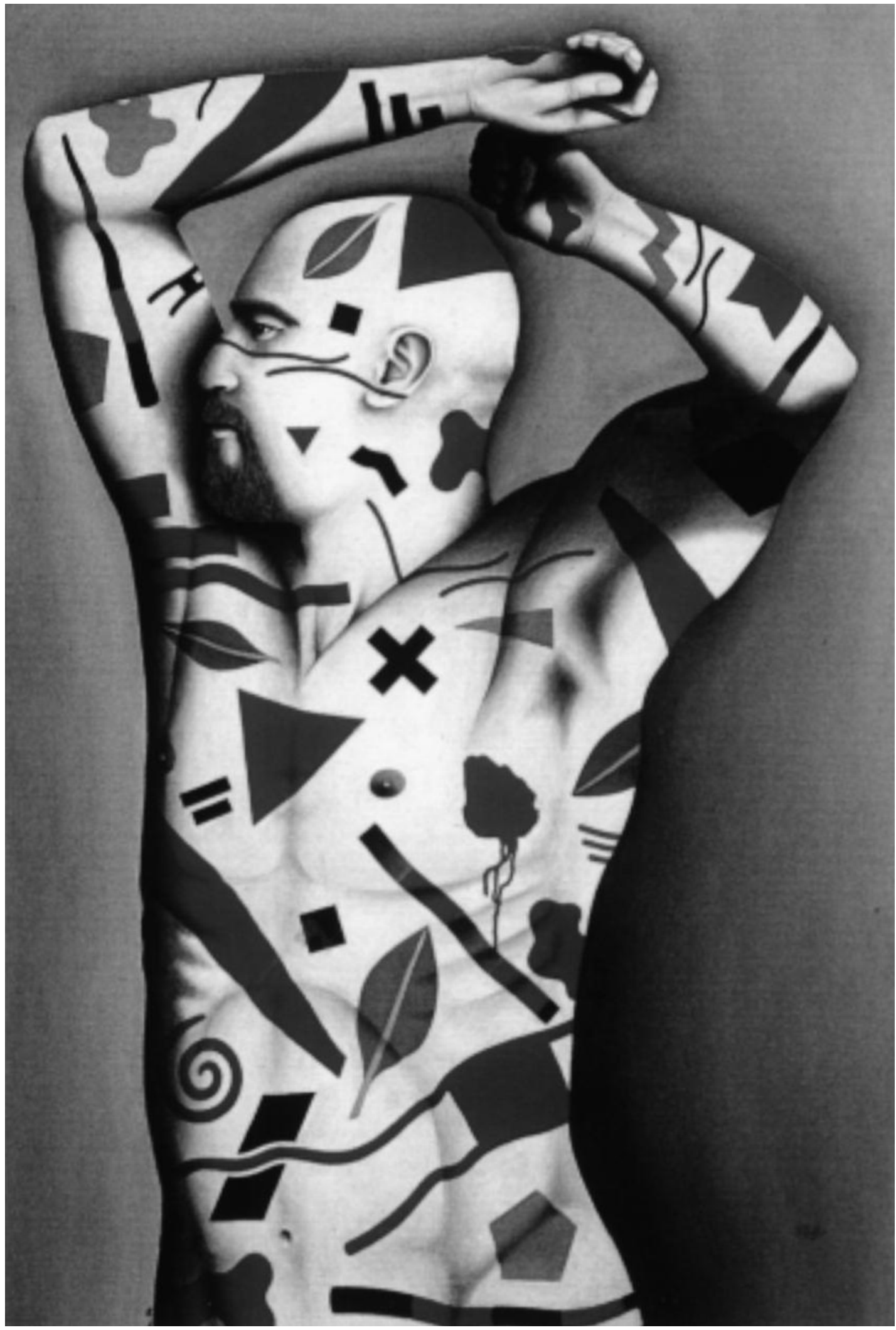

Pedro da Cruz The Illustrated Man - Self-portrait, 1996. Gengivet med Pedro da Cruz' venlige tilladelse 
ling, er af D. Epstein (1997), der beskxftiger sig kritisk indlevende med drenges egne fortællinger, idet de betragtes som dialogiske, dvs. som del af en åben og dynamisk proces.

En lignende opdeling mellem standpunktsteori og identitetspolitik på den ene side og en teori om performance og dialogisme på den anden findes hos et engelsk forskningsteam. I en oversigtsartikel, der danner grundlaget for et større, tværfagligt og kønsblandet forskningsprojekt om drenge i 11-14 års alderen, introduceres betegnelsen "drengecentreret forskning" (Frosh, Pattman og Phoenix 1998). Det godtgøres her, at der er tale om glidende overgange mellem de to tilgange, og at de ofte er samtidig til stede inden for det enkelte studie.

Titlen på deres egen artikel "Lads, Machos and Others" refererer både til drenges egne måder at betegne egen og andres maskulinitet på og til forskeres måde at konceptualisere distinktioner mellem drenge og i maskuliniteter på siden Paul Willis klassiske studie Learning to Labour (1977). Willis beskrev her det konfliktfyldte forhold mellem "the lads" og "the ear'oles", som ikke mindst blev udspillet omkring den gensidige benævnelse, og det er siden blevet fulgt op af en række lignende studier, som har vist, hvordan især klasse, race og etnicitet spiller ind i drenges (og forskeres) måder at skelne på, og hvordan de dirigeres af en kollektiv homofobi (Back 1994; Cohen 1997; Mac an Ghaill og Redman 1997; Sewell 1997). Forskellen mellem de tidligere og de senere studier er imidlertid, at mens drenges indbyrdes skelnen $\mathrm{i}$ de første betragtes som distinktioner, der repræsenterer givne sociale og kulturelle realiteter, så er pointen i de senere, at de kontinuerligt skabes og justeres i et dynamisk socialt samspil. Eksempelvis har L. Back vist, hvordan hvide arbejderklasse drenge $\mathrm{i}$ det sydlige London i 1990erne konstruerer afrikansk-caribisk maskulinitet som 'macho' i en dobbelthed af 'frygt og begær' - og i en aktuel afgrænsning over for især vietna- mesiske unge mænd, der identificeres med det 'svage og kvindagtige' og potentielt homoseksuelle.

Frosh, Pattman og Phoenix forsøger i deres artikel at anskueliggøre relevansen af begge tilgange, idet de påpeger, hvordan den interne differentiering blandt drenge og unge mænd i samspil med grænsedragningen mod det andet køn både fungerer som reelle sociale og identifikatoriske skel som noget, der er - og som diskursive konstruktioner - som noget, der gøres eller spilles ud. I deres konklusion fastholder de de to perspektiver som en nødvendig dobbelthed i den drengecentrerede forskning, der kan anvendes kritisk og reflektorisk:

"Research on boys as active subjects involves making masculinities plural and understanding and addressing them as relational identities which boys construct and inhabit. While such research aims to be interpretative and empathetic, to understand what it is like to be a young man from the point of view of boys themselves, it is critical of the ways particular masculinities $\mathrm{co}^{-}$ me to be constructed as if they were pre-given identities with essential attributes inhering in them, necessarily different from the femininities of girls and women. By addressing how and why these gender-polarised identities are asserted, proved, performed and consolidated in relation to girls and other boys, research which treat boys as active subjects, constructs masculinities as produced out of specific discursive strategies. This contrasts with more traditional readings of experience and behaviour as determined by pre-given gender identities" (1998, 140f).

Hos dette forskningsteam bliver maskulinitet altså også forstået som en diskursiv praksis, dvs. som et kommunikativt (for)handlingsudspil og derfor også som en åben, flydende og heterogen eller ligefrem dialogisk størrelse. Men samtidig understreges det, at ikke mindst unge maskuliniteter både kan og må udsættes for fortolk- 
ning og kritik af den måde, de leves og forvaltes på $\mathrm{i}$ en given situation og sættes ind $\mathrm{i}$ en større kontekst. Det er en sådan kontekst, R. W. Connell giver sit bud på, når han taler om, hvordan der på internationalt plan er ved at opstå en ny "verdenskønsorden" med nye mønstre af både materiel og immateriel magt.

Hans hovedtanke er, at opbruddet fra en imperialistisk til en post-kolonial og neo-liberalistisk verdensorden også har været et opbrud fra en given kønsorden til en anden, der måske er mindre åbenlyst hegemonisk, men som ikke desto mindre sætter sig igennem på tværs $i$ form af en "transnational forretningsorienteret maskulinitet". Den adskiller sig fra en traditionel borgerlig maskulin orden ved sin tekniskfunktionelle rationalitet, libertinske seksualitet og konsumorienterede relation til kvinder, men også igennem brugen af elitesportsmanden som legitimeringsfaktor og brugen af den sportstrænede mandekrop som marketingsredskab. Med et sideblik til poststrukturalistisk kønsteori skitserer Connell desuden en samtidig kamp med og mellem forskellige modgående tendenser. På den ene side en tendens til destabilisering af den ny verdenskønsorden i form af en kønsudjævnende pluralisme, især $\mathrm{i}$ en række af vestlige velfærdsstater. På den anden side en ny type, lokalt forankret maskulin fundamentalisme, der har givet sig forskellige udtryk fra de absolut hårde udgaver i bl.a. den afghanske islamiske Taliban-bevægelse til de blødere udgaver hos den myto-poetiske mandebevægelse i kølvandet af Robert Bly's Iron John (1991) og de nykristne "Promise Keepers", begge i USA. Dette sidste er igen et projekt, der udsættes for stærk kritik indefra af bl.a. den internationalt anerkendte amerikanske mande- og maskulinitetsforsker M. Kimmel, men som vækker genklang langt ind i den etablerede mandeforskning (jf. Seidler 1997).

\section{DANSKE OG NORDISKE DRENGESTUDIER}

Ligesom i den internationale forskning, så har studier i drenge og maskulinitet, der ligger ud over de klassiske kønsrollestudier, i en både dansk og nordisk sammenhæng haft sit udspring i den kønsbevidste skoleog uddannelsesforskning fra de sene 1970 ere og tidlige 1980ere. Allerede i Projekt Skolesprog (1979) refereredes der således gennemgående til både klasse- og kønsmæssige forhold, og det dannede fortrop for en lang række pige- og drengestudier fra "De stille piger" af M. Kristiansen (1980) over de Høje piger og lave drenge af E. Lauersen (1984) og De stakkels drenge af G. Zlotnik $(1984 / 1991)$ til De skrappe drenge (1988) eller De dygtige drenge (1988) af hhv. N. Kryger og P. Rasmussen.

I en oversigt over denne forskning (Sørensen 1992) har jeg tidligere påvist, hvordan der er tale om en tidsmæssigt forskudt parallel mellem pige- og kvindeforskningen på den ene side og drenge- og mandeforskningen på den anden. Den viser sig i en identitspolitisk erkendelsesinteresse, der bevæger sig fra den indledende fases deficitog dominanstænkning (først de stille piger, siden de lave og stakkels drenge) til den efterfølgende fases ressourcetænkning (først de høje piger, siden de skrappe eller dygtige drenge).

Medens den ressourceidentificerende pigeforskning fortsætter ind i 1990erne, blandet med en interesse $\mathrm{i}$ at etablere en ny-komparativisk og dialogisk kønsforskning (jf. antologien Køn i forandring, red. af Nielsen et. al. 1993), så kendetegnes den spredte drengeforskning langt ind i 1990erne af en særlig blanding af deficitog ressourcetænkning i en ny-maskulinistisk bølge, der også lader sig inspirere af den internationale myto-poetiske strømning. Tendensen synes særlig stærk i Danmark, hvor den bl.a. har været affødt af en offentlig debat om drenges opvækst i kvindedominerede institutioner og skoler og den heraf formodede feminisering, der kulminerede med en rapport fra Det Tværmi- 
nisterielle Børneudvalg om Drenge $i$ kvindedominerede miljøer af mandeforskerne $\mathrm{H}$. Bonde og S. Carlsen (1997). Når denne tendens bliver så stærk i Danmark, så hænger det formodentlig sammen med, at der ikke herhjemme - som f.eks. i Norge og Sverige - bliver etableret et institutionelt og ressourcemæssigt fundament under forskningen i drenge, mænd og maskulinitet. ${ }^{1}$

Parallelt med den didaktisk orienterede drengeforskning, som også har gjort sig gældende i børne- og institutionsforskningen (Kampmann 1993), så er der vokset en anden type drengecentrerede studier frem i samspil med og som en del af ungdomskultur- og medieforskningen, der bl.a. har haft et talerør i det engelsksprogede nordiske tidsskrift YOUNG (Nordic Journal of Youth Research). Her har der i løbet af 1990erne været publiceret en lang række studier af den type, Connell har karakteriseret ved den etnografiske drejning: empirisk funderet forskning blandt afgrænsede grupper af drenge og unge mænd inden for veldefinerede felter. Således i et temanummer om ung maskulinitet $(1998 / 3)$ i to artikler af hhv. norske K. Fangen om "Right-Wing Skinheads - Nostalgia and Binary Oppositions" og finske T. Tolonen "Everyone at school thinks I am a nerd...' - Schoolboys' fights and ambivalence about masculinities". I begge artikler er pointen i lighed med det hos Frosh, Patman og Phoenix refererede mønster drenges indbyrdes positioneren og profilering.

Denne type studier har på nordisk plan også manifesteret sig i en række monografier som J. Nissens svenske studie i Pojkarne vid Datorn: Unge entusiaster $i$ datateknikens värld (1993), i G. Bolins ligeledes svenske Filmbytare. Videovold, kulturell produktion och unga män (1998) og i antologien Om unga män. Identitet, kultur och livsvilkor (1995), redigeret af G. Bolin \& K. Lövgren. Også i disse studier sættes der typisk fokus på ligheder og forskelle mellem drenge, i drenges subkulturer og identitets- konstruktioner, idet tilgangen gennemgående er social-konstruktivisk. Bolin (1998) beskxftiger sig med medieformidlet vold og tager fat $\mathrm{i}$ et tabuiseret tema på en yderst kontroversiel måde, idet han etablerer en skelnen mellem drenges og mænds konkrete voldsudøvelse og deres æstetiske fascination af vold, i øvrigt i lighed med en række studier herhjemme omkring unge mænd, medier og vold (Jerslev 1996 og Sørensen 1998).

Både i YOUNG og som selvstændige studier er der i de seneste år vokset en ny type dialogisk komparatisme frem, der har udviklet sig ad flere veje. På den ene side en række bilateralt eller multi-lateralt funderede studier, hvori et eller flere nordiske lande indgår, eksempelvis Youth Cultures. ACross-Cultural Perspective (Vered \& Wulff (Eds.) 1995). På den anden side forsøg på at etablere en mere nuanceret og facetteret dialog mellem kønnede stemmer under inspiration fra bl.a. de såkaldte "gay studies" og "queer studies". Det mest paradigmatiske eksempel herpå i Norden er vel Dorte Marie Søndergaards Tegnet på kroppen fra 1996, der bygger på forskning blandt unge studerende. Via de studerendes egne fortællinger om deres forhold til studier, venner, kærester og fremtid m.v. demonstrerer D. M. Søndergaard, hvordan køn forhandles og skabes af unge i dag i skæringspunktet mellem kultur, krop og subjekt. Hun udvikler på den baggrund en model over det post-traditionelle køn med syv komponenter: tegnet på kroppen, begærsretning, seksuel position, kropsfremtoning, færdighedsrepertoire og virksomhedsfelt. En af pointerne i denne model er, at unge i dag udviser en høj grad af fleksibilitet i udformningen af de dominerende kropstegn, men at der samtidig hersker relativt snævre grænser for, hvor langt man kan gå i kombinationen af de syv grundtegn, før man så at sige bliver uigenkendelig $\mathrm{i}$ det sociale fællesskab og potentielt isoleres. Med denne model har kønsforskningen fået et redskab, der rækker ud over diskussionerne om 
lighed eller forskel, essens eller konstruktion og også synes at være brugbar i en dialog mellem natur- og kulturvidenskaberne.

\section{Perspektiver}

Som påpeget $\mathrm{i}$ indledningen, $\mathrm{og}$ som vist undervejs, så er der sket en stadig uddifferentiering af det akademiske felt, der opstod som kvindeforskning i forlængelse af det generelle opbrud i den videnskabelige verden i 1970erne. Vi har i dag både kvinde- og mande-, pige- og drengeforskning, endog med forskellige varierende betegnelser. Men samtidig er der også en tendens til - som i flere af de sidst omtalte studier - at definere kønsforskningen som en ny fælles kontekst. En kontekst, der indebærer tværgående størrelser som de omtalte "queer studies", og som er kendetegnet ved, at en række kulturbærende forskelle - foruden køn og alder især etnicitet - inddrages og sammenholdes. Dermed er hele feltet på én gang blevet mere enkelt og mere komplekst. Det er min vurdering, at der fremover stadig vil være brug for forskning med et køns- og aldersdifferentieret fokus, dvs. f.eks. for akademiske drengestudier, der kan gå tæet på drenges oplevelser af og måder at forholde sig til sig selv og verden på med vægt på det specifikke og det lokale. Men i fremtiden vil både kontekstualisering og en refleksiv perspektivering være nødvendig for at gøre sig gældende som del af et allerede dialogisk, kønskritisk forskningsfelt. Den simple og værdiladede modstilling af to køn over for hinanden, som De stakkels drenge var et eksempel på, forekommer i dag at være ganske utilstrækkelig og direkte misvisende. Men dermed skal det ikke underkendes, at den fungerede i sin samtid med stor kønspolitisk gennemslagskraft og dermed bidrog til at bane vejen for maskulinitetsforskningen herhjemme. Kun synd, at der stadig i dag er så få mandlige forskere i feltet.

\section{Note}

1. Mens der her ved udgangen er 1990erne er etableret en nordisk overbygning i form af en stilling, knyttet til det nordiske institut for kvinde- og kønsforskning (NIKK), så har vi stadig ikke et sådant fundament i Danmark.

\section{REFERENCER}

- Amit-Talai, V. \& H. Wulff (Eds.): Youth Cultures. A-Cross-Cultural Perspective. New York: Routledge, 1995.

· Back, L.: “The 'White Negro' Revisited.” A. Cornwall og N. Lindisfarne (Eds.): Dislocating Masculinity. Comparative Ethnographies. London: Routledge, 1994.

- Bolin, G.: Filmbytare. Videovold, kulturell produktion och unga män. Umeå: Borea, 1998.

. Bolin, Göran \& Karin Lövgren: Om unga män. Identitet, kultur och livsvilkor. Lund: Studentlitteratur, 1995.

- Bonde, H. og S. Carlsen: Drenge i kvindedominerede miljøer. Kbh.: Det Tværministerielle Børneudvalg, 1997.

. Connell, R. W.: "Masculinities and Globalization". Men and Masculinities 1998/1: 3-23.

. Connell R. W.: "Teaching the Boys: New Research on Masculinity, and Gender Strategies for Schools". Teachers College Record 1996/2: 206235.

- Cornwall, A. \& N. Lindisfarne (Eds.): Dislocating Masculinity. Comparative Ethnographies. London: Routledge, 1994.

- Davies, B.: "Constructing and deconstructing masculinity through critical literacy". Gender and Education 1997/1: 9-30. (Special Issue: Masculinity and Education).

. Epstein, D.: “'Boyz Own Stories: masculinities and sexualities in school". Gender and Education 1997/1. (Special Issue: Masculinity and Education).

- Fangen, Katrine Fangen: "Right-wing Skinheads - Nostalgia and Binary Oppositions". YOUNG (Nordic Journal of Youth Research) 1998/3: 3349. (Special Issue on Young Masculinities).

- Frosh, S., R. Pattman og A. Phoenix: "Developing 'Boy-centred' Research". Journal of Youth Studies 1/1998:125-142.

. Haywood, C. og M. Mac an Ghaill: "Materialism and Deconstructivism: education and the epistemology of education". Cambridge Journal of Education 1997/2: 261-272. 
- Jerslev, A.: "Violence and the Body in Contemporary Action and Horror Films". YOUNG (Nordic Journal of Youth Studies) 1996/4:39-54.

. Kampmann, J.: "Kønnets betydning i småbørns relationsdannelse". I: A. M. Nielsen et. al. (red.): Kon i forandring. Kbh.: Forlaget Hyldespjæt, 1993.

. Kristiansen, Marianne: "De stille piger: mindreværd, selvværd, pigefrigørende pædagogik". Kontekst $1980 / 40$.

- Kryger, N.: De skrappe drenge og den moderne padagogik. Kbh.: Unge Pædagoger, 1988.

- Lauersen. E.: Høje piger-lave drenge: social differentiering, karakterer og elevsituation i gymnasiet. Aalborg Universitetsforlag, 1984.

- Lees, S. (Ed.): Gender and Education. Special Issue: Masculinity and Education 1997/1.

- Mac an Ghaill, M.: The Making of Men: Masculinities, Sexualities and Schooling. Buckingham and Philadelphia: Open University Press, 1994.

- Mac an Ghaill, M. \& P. Redman: "Materialism and Deconstructivism: education and the epistemology of identity". Cambridge Journal of Education 1996/2: 261-272.

- Nayak, A. og M. Kehily: "Playing it straight: masculinities, homophobias and schooling". Journal of Gender Studies 1996/2.

- Nielsen, A. M. et. al. (red.): Køn i forandring. Kbh.: Forlaget Hyldespjæt, 1993

- Nissen, Jörgen: Pojkarna vid Datorn: Unge entusiaster $i$ datateknikens värld. Stockholm/Stehag: Symposion, 1993.

- Projekt Skolesprog: Skoledage 1-2. Kbh./Kongerslev, Unge Pædagoger /GMT, 1979.

- Rasmussen, P.: Dygtige drenge: drenge med hoje karakterer i gymnasiet. Aalborg Universitetsforlag, 1988.

- Seidler, V. J.: Man enough. Embodying masculinities. London: SAGE, 1997.

- Søndergaard, D. M.: Tegnet på kroppen. Køn: Koder og konstruktioner blandt unge voksne i Akademia. Kbh.: Museum Tusculanum, 1996.

- Sørensen, A. Scott: Kønnets kultur - om unge og ungdom. Århus: Børne- og Ungdomskultursammenslutningen, 1992. (Også udkommet som temanummer 23 af tidsskriftet BUKS).
- Sørensen, A. Scott: "Det er dig selv, der er der. Rollespil som medie og markør i ungdomskulturen”. BUKS 1998/39:26-43.

. Tolonen, Tarja: “'Everyone in school thinks I am a nerd...' - Schoolboys' fights and ambivalence about masculinities". YOUNG (Nordic Journal of Youth Research) 1998/3: 4-18. (Special Issue on Young Masculinities).

. Widersprüche 1995/56-57 (Special Issue: Männlichkeiten).

- Willis, P.: Learning to Labour: How Working Class Kids get Working Class Jobs. London: Saxon House, 1977.

- Zlotnik, Gideon: De stakkels drenge. Kbh.: Reitzel, 1984 og 1991.

\section{SUMMARY}

The article outlines the new international research area, the so-called "Boyhood Studies" and the corresponding Nordic boyhood studies that are seen in interaction with on the one hand the recent men's Studies and masculinity research and on the other hand the more established women's- and gender studies. The field is described with references to central theoretical and methodological positions within the humanities and social studies $d u$ ring the last decades. On this background, advantages and disadvantages of the current differentiation and the many different concepts are discussed as well as the future perspectives of the field.

Anne Scott Sørensen, lektor, lic. phil. ved Institut for litteratur, kultur og medier og centerleder ved Center for Kvinde- og Kønsstudier, Syddansk Universitet, Odense. 


\section{"Det føles \\ ikke-mandigt på en måde"}

\section{Mænd og infertilitet}

Af Tine TJørnhøJ-Thomsen

\section{Maskulinitet og evnen til at repro- ducere sig selp er tat forbundne. Holder myten om, at barnloshed er varst for kvinder og infertilitet parst for mand?}

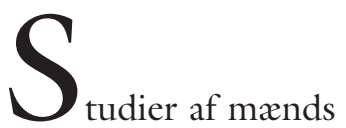
tanker, erfaringer og følelser i forbindelse med deres reproduktive liv har endnu ikke manifesteret sig på de velassorterede boghandleres hylder eller i artikeldatabaserne. Der er således ingen eller kun få fund, når man søger litteratur om mænd og reproduktion, mænd og infertilitet og lignende. Kønsstudier har primært været kvindestudier; spørgsmål om reproduktion, familie og børn har overvejende været udforsket fra kvinders perspektiv, og sammenlignet med moderskabet er det begrænset, hvad der er skrevet om faderskabets sociale, kulturelle og symbolske betydninger. Inden for det sundheds- og samfundsvidenskabelige område er der ikke produceret megen viden om det komplekse felt omkring mænds tanker, følelser og erfaringer om faderskab, reproduktion, krop og seksualitet.

Interessen for faderskabet er imidlertid øget inden for de seneste tre årtier både politisk og i forskningen. Man taler om det moderne faderskab, om ændringer i fader- 
CVELSE Nr. I8.

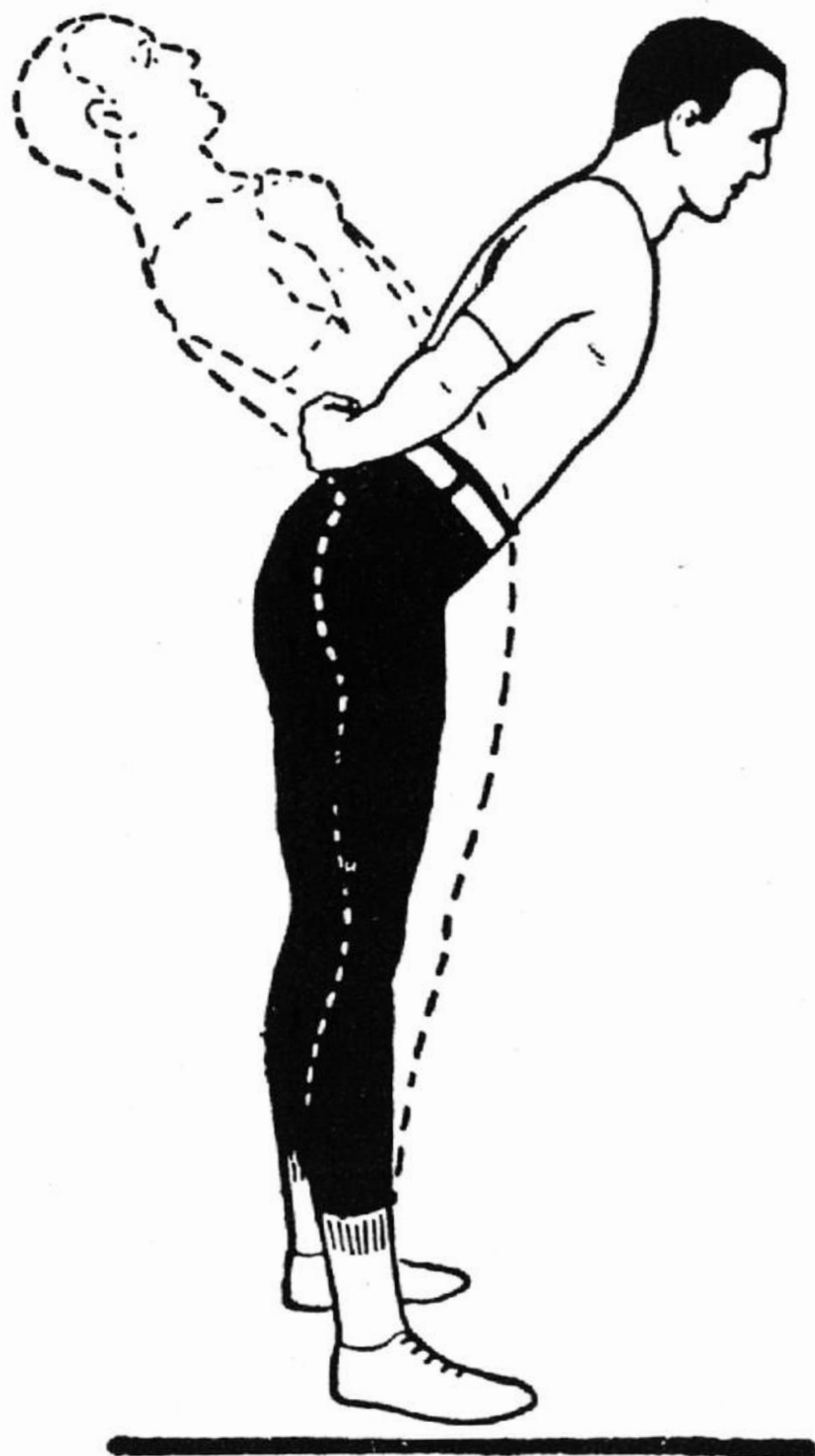

Fig. I Io. 
skabets betydninger og praksisser og diskuterer samtidig omfanget og implikationerne af disse ændringer (cf. Gillis 1992, 1996, Bergsten og Bäck-Wiklund 1996, McKeown, Ferguson, og Roony 1998, Hagström 1996, Lupton og Barcley 1997). Det moderne faderskab er, påpeges det, flertydigt og modsætningsfuldt med mange indbyggede spændinger og paradokser. De svenske forskere Birgitta Bergsten og Margareta Bäck-Wiklund (1996) refererer til en række undersøgelser, der peger på, at mænd nu er mere involveret i omsorgen for børnene og i opgaver i hjemmet, end de var tidligere, og at gængse grænser mellem moderskab og faderskab er i opbrud og til forhandling. Men undersøgelser viser også, at den kønsspecifikke arbejdsfordeling, hvad angår samvær med samt omsorg og ansvar for børnene, ikke har rykket sig markant (ibid.).

Det moderne faderskab har ikke desto mindre givet mænd mulighed for at tage del i forældreskabet på en radikalt anderledes måde end deres egne frdre (cf. Olsen 1999, Gillis 1996), og dette er, påpeger Deborah Lupton og Lesley Barclay i deres bog Constructing Fatherhood. Discourses and experiences (1997), med til at forandre traditionelle opfattelser af maskulinitet (Lupton og Barcley 1997, 1). Men faderskabet har imidlertid ikke spillet nogen hovedrolle i studier og begrebsliggørelser af maskuliniteter, hvor det indtil nu er emner som fysisk kropsudøvelse, sport, uddannelse, lønarbejde og seksuelle aktiviteter, der har været i centrum (ibid., 4).

Denne artikel beskæftiger sig med temaet "maskuliniteter" ved at belyse det relativt ubeskrevne felt, 1 der rummer mænds tanker, erfaringer og følelser i forbindelse med de aspekter af deres liv og identitet, som vedrører det at blive og at være far. Artiklen anskuer dette felt gennem en særlig optik leveret af infertile og barnløse mænd og deres partnere. Den bygger på afsnit i min ph.d-afhandling, Tilblivelseshistorier. Barnloshed, slagtskab og forplantningsteknologi $i$
Danmark (Tjørnhøj-Thomsen 1999), der i sin helhed udforsker de individuelle, sociale og kulturelle implikationer af infertilitet, ufrivillig barnløshed og brug af forplantningsteknologi. ${ }^{2}$ Artiklens empiriske afsæt er infertile og barnløse mænds og kvinders fortællinger, deres dialoger med hinanden, andre barnløse og forskeren om deres infertilitet og barnløshed og om de overvejelser, de gør sig om alternative muligheder for at få børn. Her tænker jeg på de muligheder, som forplantningsteknologien tilbyder: Det drejer sig om teknikker som donorinsemination, IVF (In Vitro Fertilisation eller reagensglasbefrugtning) og mikroinsemination. Men jeg tænker også på adoption, som er et alternativ, der også overvejes, selv om langt de fleste par i første omgang forsøger at få deres “eget" barn. ${ }^{3}$

Det er fra dette særlige perspektiv, at artiklen belyser mænds forestillinger om sig selv som fædre og del af en familie, deres og partnerens reaktioner og håndtering af deres infertilitet og barnløshed og deres forsøg på at komme overens med infertiliteten, forplantningsteknologien og måske et faderskab, der ikke forbinder dem genetisk til deres børn. Det skal understreges, at de infertile mænds tanker om - måske - at blive og være fædre ikke kun vedrører den specifikke relation til de mulige børn. Mændene refererer til kropsopfattelser, deres egen barndom og forholdet til forældre, søskende, partneren, til kolleger, venner og andre mænd. Mændene tegner således selv konturerne af forskellige relationelle og sociale kontekster, som må medtænkes i analyse, forståelse og begrebsliggørelse af deres liv. Ved for eksempel at referere til deres barndom og alderdom bringer de betydninger af generationalitet og tid på banen; og ved at referere til deres partner bringer de samtidig betydninger af køn og konjugalitet ${ }^{4} \mathrm{i}$ forgrunden. Faderskaber og maskuliniteter - som her refererer til de ideer og praksisser, der er forbundet med at blive og være far og mand - konstitueres under alle omstændigheder relationelt og kontekstuelt. 
I artiklens to første afsnit præsenteres en overordnet ramme til forståelse af de individuelle, sociale og kulturelle implikationer af infertilitet og barnløshed. De efterfølgende afsnit stiller skarpt på køn og belyser mænds tanker og følelser om deres reproduktive liv gennem en sammenligning med kvinders tilsvarende tanker og følelser. Artiklens sidste to afsnit fokuserer primært på mændenes reaktioner på og håndtering af deres dårlige sædkvalitet og infertilitet.

\section{INFERTILITET OG USIKRE LIV}

Infertilitet kan defineres som den manglende evne til at gøre eller blive gravid (cf. Lundström 1998). Infertiliteten erkendes først som et problem, når et par ønsker og forsøger at få et barn, og altså når de sociale implikationer bliver synlige (Koch 1989).

Når parret selv i ca. et år forgæeves har forsøgt at blive gravide, vil de i lægefaglig forstand være "ufrivilligt barnløse".

Fagfolk klassificerer de mange årsager til parrets ufrivillige barnløshed i tre grupper, i nogen grad afhængig af, i hvis krop årsagen til barnløsheden kan lokaliseres. Én tredjedel beror på "kvindelige faktorer", en anden tredjedel skyldes "mandlige faktorer" $o g$ for en sidste tredjedels vedkommende kan der ikke udpeges nogen egentlig årsag til parrets barnløshed, der vil være tale om uforklarlig barnløshed (Nyboe Andersen et. al. 1996). 5

Denne tredeling giver imidlertid ikke altid mening, fordi det, der forst blev defineret som årsag til parrets barnløshed, siden kan ændre sig som en følge af den nye viden, der opnås qua nye undersøgelser og behandlingsforsøg samt forskellige lægers fortolkninger heraf. At være udpeget som den infertile part afstedkommer ofte mindreværds- og skyldfølelse, og dårlig samvittighed over for partneren (og måske dennes familie) samt usikkerhed om forholdets holdbarhed (Tjørnhøj-Thomsen 1999, 107). Men hvorvidt barnløsheden beror på en mandlig eller kvindelig faktor har også andre implikationer. For der eksisterer en historisk, kulturel og institutionel betinget skrvhed i den medicinske videnskabs interesse for og følgelig viden om kvinders vis-avis mænds reproduktive liv. Andrologi er læren om sygdomme i de mandlige reproduktionsorganer (Lundström 1998, 61) og altså den mandlige pendant til det veletablerede medicinske speciale, gynækologi. Andrologi er imidlertid - forunderligt nok - ikke et godkendt medicinsk speciale (ibid.) og har derfor ikke tiltrukket yngre forskere og potentielle "vidensskabere" i samme omfang som gynækologien. Det har konsekvenser for behandlingstilbuddene til mænd og - som vi skal se - deres håndtering af infertiliteten. En fertilitetslæges bemærkning om, at de på hans klinik også er "begyndt at tage bukserne af mændene" illustrerer denne kønnede skævhed, men signalerer også den stigende interesse for andrologien inden for de seneste år. Nogle par har ikke desto mindre oplevet, at de selv måtte tage initiativ til og insistere på at få (hele) manden og ikke kun hans sæd undersøgt.

De individuelle og sociale implikationer af infertilitet og ufrivillig barnløshed 6 kan i første omgang forstås i forhold til den uorden, diskontinuitet og usikkerhed, tilstanden skaber i individuelle liv (cf. Becker 1994). En uorden, der starter med kroppen, hvis reproduktive uformåen samtidig truer forventningerne til en særlig livshistorie, karakteristisk ved en særlig livsprogression, som blandt andet refererer til forestillinger om slægtskab (se senere).

Søger vi en mere omfattende forståelse af betydningen af denne uorden, kan vi som ét muligt udgangspunkt antage, at mennesker søger at forstå de hændelser, der overgår dem ved at sætte dem ind i en tidsfølge eller et hændelsesforløb. Det vil sige, at mennesker hele tiden skaber mening med deres erfaringer, hændelser og (egne og andres) handlinger ved at organisere og udtrykke dem i en sammenhængende, tids- 
lig orden, altså give dem narrativ form. I denne proces trækker de på, motiveres af og forsøger at handle efter det repertoire af narrativer, scenarier eller diskurser, som kulturen og det sociale liv med forskellige kraft stiller til rådighed; og i samme proces både udtrykkes og formes personlig identitet. ${ }^{7}$ Identitet er således set i dette perspektiv kontekstuel og foranderlig.

For de infertile og ufrivilligt barnløse er det karakteristisk, at den livshistorie, de gerne ville leve og fortxlle - og som for eksempel handler om at blive forældre og qua moderskab og faderskab få adgang til forskellige sociale frllesskaber - ikke udfolder sig som ventet. Infertiliteten skaber et narrativt brud, der korresponderer med en identitetsmæssig desorientering. Der opstår, som det også er beskrevet i forbindelse med pludseligt opståede alvorlige sygdomme eller invaliditet (Mattingly 1998) ${ }^{8}$, et særligt behov for at bringe livet under kontrol igen, at bevare en kontinuitet trods bruddet (Becker 1994) og om muligt genoprette en alternativ orden.

Infertiliteten afstedkommer i første omgang en følelse af at være blevet snydt. Ikke kun af kroppen og naturen, men også af den udbredte idé, at reproduktion og børn - som også andre livsforhold - er og bør være resultatet af individuel kontrol, valg og ansvarlig timing (Wirtberg 1992, Lundin 1997). Mange par har sammen og hver for sig brugt prævention $\mathrm{i}$ årevis $\mathrm{i}$ forestillingen om at kontrollere, hvad der anses for at være kroppens naturlige, reproduktive potentiale. De har søgt at undgå uønsket graviditet og gjort sig overvejelser om, hvornår og med hvem de skulle have børn, samt forhandlet indbyrdes om hvilke betingelser der skulle være opfyldt, før de ville have børn. Mange lægger vægt på uddannelse, fast tilknytning til arbejdsmarkedet (det er især kvinderne) samt stabile sociale, boligmæssige og økonomiske forhold som en forudsætning for at sætte børn i verden, eller "blive klar til børn", som det udtrykkes.
Når børnene så ikke kommer som håbet, forventet eller planlagt, sker der et brud i det liv, de havde ventet at leve. Mange føler, de har mistet kontrollen med eget liv og fremtid (betydningerne af dette brud skal vi se nøjere på i næste afsnit). Samtidig kommer mange barnløse par til at leve en "hvis-nu" tilværelse, hvor de i længere perioder, også selv om de ikke ønsker det, kommer til at indrette deres liv efter graviditeten eller børnene, som måske snart kommer. De oplever at leve i et limbo med "pauseknappen trykket ind", som én formulerede denne fastholdelse i tid.

Det er det narrative brud og fastholdelsen i tid, der i første omgang forbinder infertiliteten og barnløsheden med lidelse. Infertiliteten skaber usikkerhed om fremtiden og bevirker identitetsmæssig desorientering: "Hvem skal jeg så være?" er blot et eksempel på de spørgsmål, infertiliteten rejser. De infertile både skuer tilbage i livet for at søge forklaringer på det ubegribelige og svar på spørgsmål som hvorfor mig/os og hvorfor nu, ligesom de søger at forestille sig forskellige mulige løsninger på deres barnløshed og dermed også acceptable liv(shistorier) og identiteter. Mange søger i første omgang hjælp i forplantningsteknologien. Men der opstår under alle omstændigheder et refleksions- og reformuleringsrum, hvor kulturelle værdier omkring tilblivelse, slægtskab og reproduktion, der almindeligvis tages for givet, må tages op til revision og omformuleres.

\section{INFERTILITET OG SLÆGTSKAB}

De individuelle, kulturelle og sociale implikationer af infertilitet, barnløshed og forplantningsteknologi må forstås i forhold til historisk og kulturelt betingede forestillinger om slægtskab. Et begreb, der rummer og forbinder moderskab, faderskab, forældreskab, familie og generation. Nye og anderledes familieformer genererer nye måder at være forældre på, og moderskab og faderskab tænkes, defineres og praktiseres bå- 
de i relation til hinanden og forskelligt i tid og rum (Gillis 1992, 1996 og Rosenbeck 1987). Ændringer i faderskabets betydninger er for eksempel nært forbundet med ændringer i moderskabets betingelser og vilkår (cf. McKeown, Ferguson og Roony 1998).

Den britiske antropolog Marilyn Strathern (1993) karakteriserer moderne vesteuropæisk slægtskab som en relationel kontekst, hvor slægtninge omgås med specifikke forventninger til netop slægtninges omgang med hinanden. Slægtskab betegner sociale relationer, forbundethed og samværsformer af en ganske særlig beskaffenhed og tidslig struktur. Men det, der gør slægtskabsrelationer særegne i forhold til andre sociale relationer, er, påpeger Strathern, forestillingen om slægtskabsrelationernes tilblivelse $\mathrm{i}$ den biologiske og kropslige forplantningsproces (sex, befrugtning, graviditet og fødsel) og altså slægtskabets forankring i, hvad man kunne kalde en kulturspecifik tilblivelseshistorie. En historie, der altså handler om, hvorledes personer, særlige relationer og specifikke identiteter bliver til. Det drejer sig således også om kønsidentitet, fordi det, der kulturelt konstrueres som kvindeligt og mandligt, trækker på viden om mænds og kvinders specifikke, komplementære og asymmetriske roller i reproduktionen.

Det er viden om tilblivelsens biologiske og kropslige processer, der tilfører slægtskabsrelationerne en særlig symbolsk betydning som varige og bærere af særlige følelser. Her er tillige ideer om autenticitet på spil. At blive, hvad der kulturelt og socialt anskues som "biologisk" eller "rigtig", far, mor og familie, er at blive såvel genetisk som kropsligt forbundet til et fælles barn og altså afhængig af, at kroppene hver for sig og i fællesskab formår at være både aktører og bidragydere i denne særlige tilblivelseshistorie. Den dominerende betydning, biologi og genetisk forbundethed spiller i vores samfund, finder imidlertid ikke universel udbredelse, ligesom viden om og fortolkning af tilblivelsen har ændret sig over tid. ${ }^{9}$ Barnets og forældrenes tilblivelseshistorier handler heller ikke kun om biologiske og kropslige processer. Der lægges også vægt på, som det blev nævnt i det tidligere afsnit, at barnet skal være timet, ønsket og produceret i privathed og kxrlighed og med en særlig udvalgt partner.

Den tilblivelseshistorie, de fleste gerne vil erfare og fortælle, anfægtes i første omgang af infertiliteten og ændres senere radikalt ved mødet med forplantningsteknologien. Kort fortalt bliver reproduktionen uafhængig af sex, befrugtningen uafhængig af kroppen; teknologien intervenerer i, disciplinerer og synliggør kroppen, dens substanser og forplantningsprocessen og tilføjer derved nye valg, nye erfaringer og nye måder at se og erfare krop og selv på. Eksperter og klinikpersonale (og donorer) bliver nye aktører i tilblivelsen, og gængse grænser mellem det intime, det private og det offentlige forrykkes. ${ }^{10}$

De infertiles og barnløses længsler og lidelser er komplekst forbundet med forestillinger om slægtskab og en kulturspecifik tilblivelseshistorie og vedrører både slægtskabets sociale og relationelle dimensioner og dets kropslige og biologiske aspekter. Før jeg går over til at diskutere køn i den sammenhæng, skal jeg belyse hvad, der i mere generelle termer er på spil for de barnløse mænd og kvinder, og hvad, det er for "brud", infertiliteten afstedkommer i deres liv.

De infertile og barnløse er udelukket fra at tage del i det eksklusive, daglige samvær med børn og at være en familie og skabe et hjem. Ligesom de er udelukket fra de specifikke sociale fællesskaber og ritualer, som erfaringerne $\mathrm{i}$ forbindelse med at kunne få og have børn og familieliv giver adgang til og forbinder (Tjørnhøj-Thomsen 1999, 79 ff). Disse udelukkelser får, som det senere vil fremgå, på forskellig vis konsekvenser for kompetence, selvfølelse og identitet. Men der er mere på spil, som vedrører slægtska- 
bets tidslige og generationelle dimensioner og et bestemt livsprospekt. Tanker om børn refererer ikke kun til forestillinger om fremtiden, men også fortiden. Flere peger på, at det at få børn og familie giver dem en mulighed for at genopleve, repetere og om muligt revidere egne barndomsoplevelser og egne forældres måde at være forældre på. Mange har svært ved at forestille sig at blive gamle med partneren uden børn. Børn er på den ene side et produkt af en særlig relation mellem parterne, men forventes også at tilføre relationen en ekstra dimension af frlleshed (cf. Jagd 1998) og permanens. Infertilitet og barnløshed befordrer derfor ofte spekulationer om det fremtidige liv med partneren. Mange giver udtryk for, at de qua børn kan genskabe dele af sig selv og reproducere såvel egne som partnerens egenskaber. Længslen efter at reproducere sig selv - få "egne” børn eksponeres i betydningen af "at ligne", som de fleste også har mødt i velkendte diskussioner om hvem i familien, der fysisk eller mentalt ligner hvem. Sådanne diskussioner skal ses som en symbolsk bekræftelse af familien som et genetisk fællesskab (mellem genealogiens afdøde slægtninge og de levende).

Set gennem den infertile og barnløse optik bliver det tydeligt, at det at kunne få og have børn giver adgang til sociale fællesskaber og identiteter i tid og rum. Det er at blive del af samfundet, genealogien og historien. Det tydeliggør også, at slægtskabsrelationerne er integreret $\mathrm{i}$ og forbinder andre sociale fællesskaber.

Når de barnløse søger at indkredse, hvad de selv forstår og forventer af deres "egen" familie (og her refererer de især til forældre, bedsteforældre og søskende), taler de om den, som "noget man har, uanset hvad", "familien vil altid være der", og "familien er der, hvor du kan være dig selv". Også fra dette perspektiv repræsenteres slægtskabsrelationer som varige og permanente. De barnløses egne oplevelser af familien og udvalgte familiemedlemmers re- aktion på deres situation får i nogen grad dette billede til at krakelere. De demonstrerer, at forventninger til familien, hvorledes de indfries og den særlige forbundethed, der forestilles at eksistere mellem slægtninge, uvægerligt medieres af forestillinger om køns- og generationsforskelle og individuelle præferencer (Tjørnhøj-Thomsen 1999, 105ff). For eksempel forventer mange barnløse (især kvinderne) en særlig lydhørhed og omsorg fra deres egen mor eller søster, mens de ikke nærer samme forventninger til en far eller bror.

\section{KØN SOM EN FORSKEL, DER GØR EN FORSKEL}

I infertile og barnløse mænds og kvinders fortællinger og dialoger om deres situation refererer de bestandigt til køn som en forskel, der gør en forskel. De sammenligner og generaliserer forskelle mellem mænds og kvinders oplevelser af og håndtering af infertilitet, barnløshed og møde med forplantningsteknologien. De refererer til køn i deres måde at markere, strukturere og give mening til specifikke erfaringer og praksisser på. De eksponerer derved også kulturelle forestillinger om kønsforskelle, kønnenes væsen og kønnede erfaringer. Nedenfor og i de efterfølgende afsnit skal vi se nøjere på, hvorledes køn er en forskel, der gør en forskel. Men som det vil fremgå medieres kønsforskelle af andre forskelle som for eksempel generations- og aldersforskelle og forskelle mellem mænd indbyrdes og mellem kvinder indbyrdes.

Køn træder for eksempel i forgrunden som tema, når vi går tæet på omverdenens forholden sig til ufrivillig barnløshed og forplantningsteknologien, som det kom til udtryk i den offentlige og politiske debat om kunstig befrugtning i 1995, 1996 og 1997.11 Et interessant eksempel var spørgsmålet om, hvorvidt der skulle være en fast aldersgrænse på 40 år for kvinder, når det gjaldt adgang til kunstig befrugtning. Der var mange andre udspil i den debat, så som 
hensynet til børnene og spørgsmålet om xldre førstegangsforældres forældreevne. Mest opstandelse gav det dog, da den daværende sundhedsminister foreslog en aldersgrænse for mænd på 45 år. Stemmer mod dette forslag pegede på, at mænds sædceller i modsætning til kvinders æa ikke blev dårligere med alderen. Den ældre mor forekom fra det perspektiv mere unaturlig end den $x$ ldre far. Flere ældre fædre til småbørn stod frem i medierne og tilkendegav, at de nu i fremskreden alder følte sig mere modne og parate til faderskabet (Tjørnhøj-Thomsen 1999, 76). Køn og alder blev således spundet sammen i spørgsmål om moderskabs- og faderskabsevner. Som det også blev nævnt i introduktionen, er såvel udvikling som implementering af forplantningsteknologien en kønnet affære.

\section{KØNNET ÅBENHED}

Der hersker en udbredt forestilling om, at det er godt at være "åben" om sin infertilitet og barnløshed. Denne fokusering på betydningen af åbenhed peger ikke desto mindre på, at den faktisk er svær for mange at praktisere, og at infertilitet ofte er et privat problem forbundet med skamfølelse og stilhed.

Åbenhed - det "at tale om det" især med andre i samme situation - betragtes først og fremmest som en psykisk lindring. En mand påpegede fordelen ved åbenhed således: "Det kan godt være, det lyder mærkeligt, men det er en trøst at vide, at andre har det sådan”. Hertil kommer, at fortielse og hemmelighedskræmmeri betragtes som skadeligt for sociale relationer især til familie og venner. Der kan i den forbindelse trækkes paralleller til Michel Foucaults "confessing society". Her beskriver han, hvorledes "bekendelsen" - en verbaliseret vedkendelse af tanker og handlinger er kommet til at spille en rolle i mange former for menneskelige relationer $\mathrm{i}$ vestlige samfund. Bekendelse udfolder sig altid i en særlig (magt)relation mellem den, der be- kender, og den, der straffer eller tilgiver. Til bekendelsen er også knyttet både frigørelse og lindring (Foucault 1980).

Mange føler da også en lettelse ved at få fortalt især familien om deres særlige situation. Ikke mindst fordi familien - især de potentielle bedsteforældre - spørger til børn. Åbenheden er imidlertid selektiv på flere måder. Den gxlder ikke alle i omgangskredsen i lige stort omfang, og det er heller ikke alle aspekter af infertiliteten og behandlingen, de barnløse drøfter med venner og familiemedlemmer. Hertil kommer, at mænd og kvinder håndterer det "at tale om det”, altså åbenheden, meget forskelligt. ${ }^{12}$

Forestillinger om køn fremstår her som én selektiv mekanisme ved for eksempel at forbinde følelser, åbenhed, ansvar for familiens trivsel og interesse for reproduktive emner med især kvinder. Både mænd og kvinder tilkendegiver, at mændene (sammelignet med deres partner og kvinder mere generelt) er mere "lukkede" om deres infertilitet og barnløshed blandt venner og kolleger. De "blotter sig ikke, som kvinder gør", og de er mere "blufærdige". Der er da også en tendens til i højere grad at fortie mænds infertilitet end kvinders. Langt de fleste infertile mænd har dog fortalt nære kolleger eller venner om deres problem, uden at det derfor er blevet et tilbagevendende samtaleemne. Ovenstående markeringer af kønsforskelle betyder ikke, at mænd ikke kan give udtryk for deres følelser. Snarere, at de ikke har samme traditioner og behov som kvinder for at tale om de personlige og følelsesmæssige aspekter af deres infertilitet og barnløshed eller taler om disse på en anden måde og i et andet sprog end kvinder (Schmidt 1996, 77). Mænd kan dog have svært ved at finde ord for deres reproduktive funktioner, selv når de forsøgsvis alligevel drøfter emnet med andre mænd. En infertil mand fortalte, at han havde drøftet en tv-udsendelse om faldende sædkvalitet med nogle kolleger. Han fandt det særlig interessant, at en af hans 
kolleger ikke kunne/ville udtale ordet "sæd": "Han kunne ikke sige sæd. Det var så morsomt. Han kunne ikke sige det (men sagde) de der haletudser. Hver gang ordet sæd eller sædkvalitet kom, så stoppede han op".

\section{KØNNET BARNLØSHED - KØNNET FORÆLDRESKAB}

Der er historiske og kulturelle årsager til, at mænd ikke har haft anledning eller tradition for at udveksle og tale om deres reproduktive erfaringer. De har ikke udviklet de særlige erfaringsfællesskaber, som kvinder har bygget op om deres reproduktive liv, graviditet, fødsel og omsorgen for de spæde børn, og som kvinder stadig reproducerer i vennekredsen og blandt kolleger. Kvindefællesskaber, som de infertile og barnløse kvinder i modsætning til deres partnere igen og igen bliver konfronteret med, og som de på smertelig vis føler sig udelukket fra. Disse udelukkelser er del af forklaringen på, at barnløse kvinder i langt højere grad end deres partnere giver udtryk for tab af identitet, kompetence og selvværd.

Mænd har - endnu - ikke udviklet disse fællesskaber og sproget baseret på udveksling af reproduktive erfaringer, og de bliver derfor heller ikke konfronteret med deres barnløshed i hverdagslivet på samme bastante måde som kvinder. Mænd kan i højere grad end kvinder udelukke infertiliteten og barnløsheden fra deres sociale liv, arbejdsliv og samvær med andre mænd (cf. Wirtberg 1992). De kan "bedre gemme sig i deres arbejde", som det for eksempel lyder.

Mens de barnløse kvinder igen og igen gør sig tanker om, hvorledes de skal kombinere det reproduktive liv (fertilitetsbehandlingen og mo-derskabet, de håber på) med deres lønarbejde og derved bestandigt eksponerer spændingsrummet mellem det reproduktive og det produktive arbejde i kvinders liv (cf. Franklin 1997), bringes dette tema sjældent på bane af mændene $\mathrm{i}$ deres forestillinger om en mulig fremtid med børn. Desuden lader de fleste infertile og barnløse mænd sig ikke provokere og mærke følelsesmæssigt i samme omfang som kvinder af mødet med gravide kvinder, barnevogne og småbørn: "Det kunne være rart at fă børn, men det er ikke sådan, at jeg stopper op og synker en klump, hver gang jeg ser en gravid kvinde", som en infertil mand beskriver sin - sammenlignet med partnerens - mere nøgterne reaktion. Barnløsheden går dem - efter hvad de selv og deres partnere siger - heller ikke på på samme måde (cf. Schmidt 1996). De “tager en ting ad gangen" eller "tager tingene, som de kommer". "Det er nok sværere for min kone", eller "det er værre for kvinder" lyder budskaberne.

Ved at fokusere på deres partners afsavn og lidelser bekræfter og betoner mændene de kulturelle betydninger af moderskabet for kvinders liv og identitet. Mens deres egne afsavn og betydninger af faderskabet for deres liv har tendens til at træde i baggrunden.

Det betyder imidlertid langt fra, at de er upåvirkede af deres infertilitet eller deres barnløshed. Netop fordi de er i en situation, hvor de gerne vil have børn, men ikke umiddelbart kan få det, registrerer de med særlig opmærksomhed andres forældreskab og andre mænds faderskab. Som en mand forklarede det: "De sidste to år, hver eneste gang der kører en person forbi på en cykel, så kigger jeg faktisk efter, om der sidder en børnestol på cyklen. Og det er virkelig noget, jeg sådan fokuserer på, Nå, for søren. Han har ligegodt et barn, Hvor gammel mon han er? Hvad mon han laver, og hvad mon han er for en. Tænk, han er ligegodt far".

Citatet illustrerer, at de infertile og barnløse mænd i stigende omfang bliver konfronteret med barnløsheden, fordi mænd i tæt, kropsligt samvær og leg med deres børn er blevet mere synlige i hverdagslivet og i reklamerne. Disse mere og mere iøjnefaldende repræsentationer af de 